\title{
THE
}

WASHINGTON BIOLOGISTS'

\section{FIELD CLUB}





\title{
MEMBERS' BOOK
}

\author{
$\mathrm{OH}$ T $\mathrm{TE}$
}

WASHINGTON BIOLOGISTS'

\section{FIELD CLUB}

PRINTED FOR THE CLUB

W A SHINGTON, D. C.

MARCH I4, 1904 

-

$-$

- 


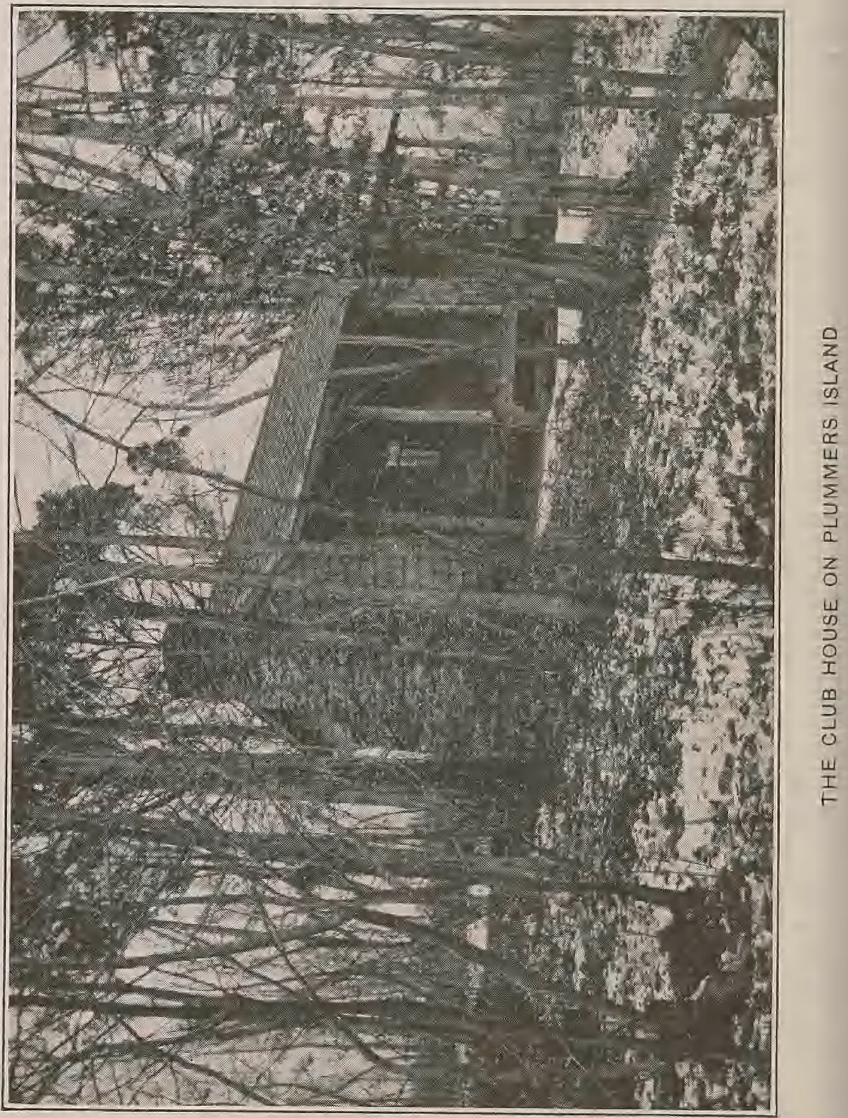




\section{Q \\ 35 \\ W 319 \\ RBB \\ HISTORICAL SKETCH}

N the late autumn of I899 Mr. Charles I. Pollard, one of Washington's enthusiastic botanists, while upon a 1 visit to Philadelphia accepted an invitation to spend a day at a naturalists' camp which had recently been established in a neighboring part of New Jersey. He was thoroughly impressed with the value to the working biologist of such a base of operations, and on his return to Washington outlined to several of his scientific friends a scheme for a similar field camp in this vicinity. An organization was effected early in 1900 , under the name of The Washington Biologists' Field Club, and committees were appointed to draft by-laws and to investigate desirable localities. At a meeting held shortly after, at the home of Mr. Pollard, the by-laws were adopted; Mr. Pollard was elected President and Mr. Edgar Brown Secretary-Treasurer. The committee on site reported on the nierits of the several localities suggested by the members, and it was decided to locate, if possible, in the neighborhood of Upper Marlboro, Maryland, some twenty miles southeast of Washington. A few days later the members were called together again, and the President stated that, in company with Mr. William Palmer, he had visited Upper Marlboro and had found a small cottage upon the Bonaparte property exactly suited to the needs of the Club. It was decided forthwith to rent the house and furnish it. An assessment of $\$ 5$ per member was inade, netting a sum sufficient to pay a year's rental and to buy the necessary furniture and utensils. The outfit, which was not extensive, included a small stove, three plain tables, six chairs, six cots, a large hanging lamp, two lanterus, a skillet, an ax, tin plates and cups, and a set of knives, forks, and spoons.

A year and a half was spent in this house, hardly a week passing without several members making the trip from Washington; but the difficulties of access were too great to make the expeditions thoroughly enjoyable, and 
the Club accordingly decided to cast about for another location more readily accessible. At last such a one, ideally perfect, was found in Plummers Island, situated in the Potomac River near the Maryland shore some seven miles above Washington. There was, however, no building upon the island, and it looked as if tents would have to be used for shelter. At this juncture some one proposed the building of a house, a typical woods camp, the work to be done by members, and expenses thus kept within moderate bounds. It was estimated that for about $\$ 200$ a house could be built which would answer every purpose ; and two of the members who had had experience at building, Messrs W. R. Beattie and William Palmer, were appointed to draw plans, to negotiate for building materials, and to call on others for assistance. In view of the contemplated building operations and probable growth of the Club, it was thought best to reorganize and incorporate under the laws of the District of Columbia. This was accordingly done; Mr. W. P. Hay was elected President and Mr. E. L. Morris Secretary-Treasurer. Plummers Island was leased for a period of five years at an annual rental of $\$ 30$ and building operations were begun.

It will not be necessary to describe in detail the erection of the house, the difficulties experienced in conveying the material to the bank of the river, and the seemingly interminable labor of transporting it from there by wire trolley to the highest point on the island, a rocky crest seventy-five feet above the water, which had been chosen as a building site. All who could set to work with a will, and the house gradually arose. The structure was begun late in the spring, and the first snows of winter had fallen before the final and consummating feature, the great stone chimney, was completed. The old furnishings of the Marlboro house were moved into the new quarters, and the house warming was held on Thanksgiving Day, I gor.

The club-house as it now stands is a one-story building, containing one large room, 44 by 28 feet, and a small kitchen, $\delta$ by 9 feet, at the rear. A broad porch extends 
the full length of the house on the side facing the river. At one end of the large room is the fine open fireplace, wide enough to receive four-foot logs and high enough to throw out a great volunie of heat. At the opposite end are the lockers for the private use of members, and at frequent intervals along the walls there are shelves to accommodate the books and common property of the Club. The cots and blankets are kept upon a platforns built above the lockers. Heavy curtains may be drawn across the room near this end, separating it from the main living-room. The litchen contains the cook-stove, culinary utensils, table service, and supplies of food. The house itself is covered on the outside with unpainted cypress shingles laid upon a solid sheathing of lumber and is lined on the inside with heavy building paper. It can be made comfortable on the coldest nights experienced in this latitude, and, as the register shows, has been used by the members at every season of the year and in every sort of weather.

The cost of the building was slightly over the $\$ 200$ estimated, of which sum there was on hand at the beginning only $\$ 75$. With the regular dues and the entrance fees of new members, no special assessments having been made, all debts have been paid and the club now has a substantial balance in the treasury. The present membership numbers thirty-three.

A thorough biological survey of the island is in progress, and the Club hopes in time to be able to set forth in appropriate form a record of the observations which its members are making. The accessibility of the ground from the terminus of the car line at Cabin John and its naturally restricted area are factors which make probable an early and successful completion of this pleasant task.

This booklet and brief historical sketch have been prepared largely for the use of the Club members, but also in the hope that prospective biological clubs in other parts of the country may be led to acquire for their use simple quarters in some wild spot where out-door life may be studied under the best of conditions. 


\section{ACT OF INCORPORATION}

We, the undersigned, being persons of full age and citizens of the United States, and a majority being citizens of the District of Columbia, pursuant to and in conformity with sections 545 to 552 , inclusive, of the Revised Statutes of the United States relating to the District of Columbia, as amended by an act of Congress entitled "An act to amend the Revised Statutes of the United States relating to the District of Columbia, and for other purposes, " approved April 23, I884, hereby associate ourselves together as a society or body corporate, and certify in writing:

I. That the name of the society is THE WASHINGTON BIOLOGISTS' FIE, I,D CIUB.

2. That the term for which it is organized is ninety-nine years.

3. That its particular business and objects are the promotion of research upon the fauna and flora of the District of Columbia and vicinity, and the general advancement of biological science, with power:

a. To hold meetings.

$b$. To acquire, hold, and convey real estate and other property.

c. To make and maintain collections of biological specimens.

d. To conduct field excursions.

$e$. To establish and maintain a club-house.

$f$. And, in general, to transact any business pertinent to a biologists' field club.

4. That the affairs, funds, and property of the corporation shall be in general charge of a Board of Managers, the number of whose members for the first year shall be nine, all of whom shall be chosen from among the members of of the club.

Witness our hands and seals this I th day of May, Igor.

CHARI,ES LOUIS POLIAAR. [I. S.]
WIIFRED H. OSGOOD.
W. P. HAY. 


\section{OFFICERS}

PRESIDENT

W. P. HAY

VICE-PRESIDENT

C. I. SHEAR

SECRETARY-TREASURER

WM. R. MAXON

BOARD OF MANAGERS

7erms expire 1904

A. A. DOOLITTTLE

W. R. BEATTIE

WILIIAM PALIMER
Terms expire 1905

W. E. SAFFORD

E. L. MORRIS

W. H. OSGOOD

HOUSE AND GROUNDS COMMITTEE

W. H. OSGOOD

WM. R. MAXON

E. L. MORRIS 


\section{B Y - L A W S}

\section{ARTICLE I}

I. This Club shall be composed of persons interested in biological science.

2. Wherever in these By-Laws the word Club is mentioned, it shall be taken to mean the corporation, and the word member or niembers of the Club shall mean member or menbers of the corporation.

\section{ARTICLE II-Members}

I. There shall be two classes of members, namely, active and honorary nembers.

2. Active niembers shall be selected from persons resident in the city of Washington or vicinity. The annual dues of active members shall be three dollars, payable at the beginning of the fiscal year, and any member more than one year in arrears for dues may be dropped at any time from the list of members by vote of the Board of Managers.

3. An entrance fee of ten dollars shall be paid by each new member.

4. Honorary members may be residents of any country. They shall not be required to pay dues, nor shall they be entitled to vote at the meetings of the Club.

\section{ARTICLE III-Officers}

I. The officers of the Club shall consist of a President, a Vice-President, and a Secretary-T'reasurer, each of whom shall hold office for one year; and six managers, in two classes of three each, whose terms of office for the first year shall be one year and two years for each class 
respectively, and whose successors shall be chosen for the full term of two years. These officers collectively shall constitute the Board of Managers; and wherever in these By-Laws the word Board occurs, it shall be taken to mean the Board of Managers.

2. The President shall preside at meetings of the Club and of the Board, and in his absence or incapacity his duties shall be performed by the Vice-President. He shall, with the Secretary-Treasurer, sign all written con1tracts and obligations of the Club and attest its corporate seal, and shall perform such other duties as the Board may assign to him.

3. The Secretary-Treasurer shall keep minutes of all meetings of the Club and of the Board, shall have sharge of the records and correspondence of the Club, and, jointly with the President, shall sign all written contracts and obligations of the Club and attest its corporate seal.

4. The Board of Managers shall be empowered to transact all business not otherwise provided for, and shall have power to fill vacancies in its own membership until the next succeeding annual election; it shall meet at the call of the President, or at the written request of any three of its members. Five shall constitute a quorum at any meeting of the Board.

\section{ARTICLE IV-Meetings}

I. The annual meeting of the Club shall be held in April of each year, at the call of the Board of Managers, notice thereof to be submitted to all members at least one week in advance. At this meeting the President and the Secretary-Treasurer shall submit reports on the general condition of the Club and its finances respectively, and officers for the ensuing year shall be elected.

2. Stated meetings of the Club may be held at such time and place as the Board may determine, and shall be held at the call of any five members of the Club. Onethird of the total membership shall constitute a quorum at any meeting of the Club. 


\section{ARTICLE; V-Elections}

I. The officers of the Club shall be elected by ballot at each annual meeting, and shall serve until the close of the meeting at which their successors are chosen. A majority of the votes cast shall be necessary to a choice.

2. Members may be elected by ballot upon the unanimous recommendation of the Board of Managers; but two negative votes shall be sufficient to defeat a candidate.

\section{ARTICLE VI-Amendments}

These By-Laws may be amended by a two-thirds vote of the members present at any meeting of the Club; but notice of the proposed amendment must first be submitted in writing to all members of the Club at least two weeks in advance. 


\section{INFORMATION FOR MEMBERS}

1. Members shall not entertain more than three guests at the island at one time, except by permission of the House and Grounds Committee, and such guests must be accompanied by the menubers inviting them.

2. All members aud visitors shall register each day while on the island.

3. No member shall at any time entertain more than one visitor overnight, except by permission of the House and Grounds Committee.

4. No member or visitor shall occupy the house for more than three sucessive nights, to the exclusion of other members.

5. Ladies, as the guests of members, are permitted to visit the Club-house on all days except the second and fourth Sundays of each month. The arrangements at the Club-house do not include conveniences for the stay of ladies overniglit; members or visitors accompanied by their wives must find accommodations elsewhere when they desire to remain in the vicinity more than one day.

6. No member or visitor shall remove from the island any plant or animal, when such removal will detract from the natural beauty of the island or endanger the existence of the species there.

7. No living tree shall be cut, trimmed, or in any way mutilated except by permisson of the House and Grounds Committee.

8. No outdoor or camp fires shall be made on the island except by permission of the House and Grounds Committee.

9. Members must extinguish all fires and lights before leaving the house unoccupied. 
Io. Members must secure their own firewood or replace the amount used by them.

II. The house is supplied by the Club with necessary cooking utensils, illuminating oil, and staple provisions, including flour, sugar, salt, and pepper. In case any of these is found lacking, the House and Grounds Cominittee should be notified.

I2. The house must be kept clean and orderly. All dishes, cooking utensils, and tools must be put in their proper places, in good condition, after using. All refuse matter must be burned or thrown into the river.

r3. One boat, to serve as a ferry between the Maryland shore and the island, must remain in the branch.

I4. The boats must be left securely fastened and the oars kept at the house when not in use. When more than one party visits the Virginia shore on the same day, every effort should be made to have one boat returned to the island for the use of later parties.

I5. Members desiring lockers should apply to the Secretary-Treasurer.

I6. It is only fair that all members should share the small amount of work necessary for the maintenance and improvement of the house and grounds. Instructions for such work will be posted from time to time by the House and Grounds Committee.

17. The House and Grounds Committee is charged with the enforcement of these rules. 


\section{E M B ER S}

W. H. ASHMEAD

U. S. National Museum.

CARLETON R. BALL ·. . . June 3, IgOI U. S. Department of Agriculture.

H. S. BARBER

U. S. National Museum.

June 3, I901

*HENRY BAUM

U. S. Department of Agriculture.

June 3, IgoI

W. R. BEATTIE

U.S. Department of Agriculture.

EDGAR BROWN . . . . . Founder, 1900

U.S. Department of Agriculture.

AUGUST BUSCK

U.S. Department of Agriculture.

M. A. CARLETON . June 3, IgOI June II, I9O3

U.S. Department of Agriculture.

June 3, IgoI

January, Igor

G. N. Colims . . Founder, rgoo

U.S. Department of Agriculture.

O. F. Cook . . . Founder, Igoo

U. S. Department of Agriculture.

FREDERICK V. COVIILE ·. . Founder, I900

U.S. Department of Agriculture.

ROLLA P. CURRIE

U. S. National Museum.

June 3, I9or

A. A. DoolitTLIE - June 3, Igor I657 Thirty-first Street.

J. W. T. DUVEL • • • • October 10, I903

U. S. Department of Agriculture.

A. K. FISHER October Io, 1903

U. S. Department of Agriculture.

E. A. Gordman . . . . November 22, Igor U. S. Department of Agriculture.

* Deceased, December 20, Ig03. 
W. P. HAY

\section{Howard University.}

T. H. KEARNEY - . • • . MaY 28, I902 U.S. Department of Agriculture.

R. E. B. McKENNEX . . October 4, I903 U.S. Department of Agriculture.

M. C. MARSH

Bureau of Fisheries.

William R. MAXoN

U. S. National Museum.

GERRIT S. MILLER

U. S. National Museum.

June 3, I9o I

Founder, I9oo

. Founder, I900

E. L. MorRis

Central Higl school.

WILFRED H. OSGOOD . . . . January, IgOI U.S. Department of Agriculture.

WILIIAM PALMER
U. S. National Museum.

CHARLES L. POLLARD .
U. S. Nationai Museum.

J. H. RILEY

Smithsouian Institution.

W. E. SAFFORD

U. S. Department of Agriculture.

Founder, Igoo

Founder, I 900

June 3, IgoI

December, Igor

E. A. SCHWARZ

U. S. National Museum.

C. S. SCOFIEID . . . . December, I9OI

U. S. Department of Agriculture.

January 29,1903

C. L. SHEAR U.S. Department of Agriculture.

Founder, I900

T. W. VAughaN Smithsonian Institution.

June 3, I90I

C. F. WHEELER

U.S. Department of Agriculture.

DAvid WhITE

U. S. National Museum.

December, I90I 


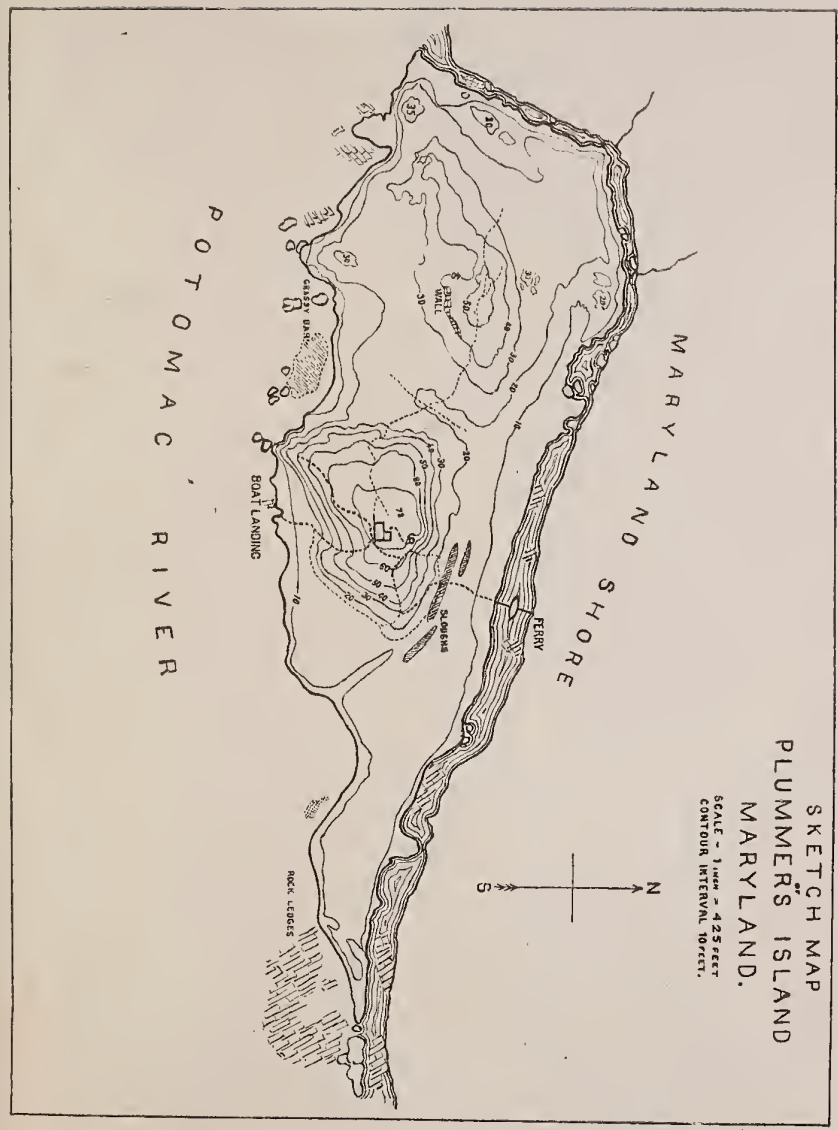





\section{$-$}




SMITHSONIAN INSTITUTION LIBRARIES

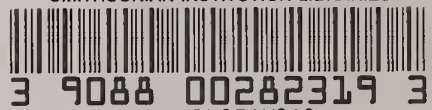

crlsrb QH35.W319

Members Book of the Washington Biologis 